\title{
'Micro-Tina' and 'Micro-Gemma' Miniature Dwarf Tomatoes ${ }^{1}$
}

\section{J.W. Scott, B.K. Harbaugh and E.A. Baldwin ${ }^{2}$}

'Micro-Tina' is a red-fruited, miniature dwarf tomato (Lycopersicon esculentum Mill.) cultivar of a type similar to 'Micro-Tom' (Scott and Harbaugh, 1989) but with sweeter flavor. 'Micro-Gemma' is a gold-fruited, miniature dwarf with superior flavor to that of 'Micro-Gold' (Scott and Harbaugh, 1995). These companion releases provide tomato cultivars that are genetically smaller (plant, fruit, leaves, and stems) than are normal dwarf cultivars. They can be grown in small pots, on window sills, or in small hanging baskets. They provide a well-proportioned plant ideally suited to commercial growing, shipping, and marketing because of their small size and light weight.

\section{Origin}

'Micro-Tina', tested as Fla. 7876, was increased in the $\mathrm{F}_{10}$ generation after a cross between 'Micro-Tom' x 'Sugar' (PI 270248). 'Micro-Tom' (Scott and Harbaugh, 1989) provided the miniature dwarf plant characteristics while 'Sugar' was the source of high fruit sweetness. 'Micro-Gemma', tested as Fla. 7878, was increased in the $\mathrm{F}_{10}$ generation after a cross between Fla. 7565, an inbred closely related to 'Micro-Gold' (Scott and Harbaugh, 1995), and 'Sugar' (PI 270248). Fla. 7565 provided the miniature dwarf plant characteristics while 'Sugar' was the source of high fruit sweetness. Selections for both cultivars emphasized sweet but tomato-like flavor, and, in the early generations, high soluble-solids refractometer readings.

\section{Description}

\section{'Micro-Tina'}

'Micro-Tina' had a short, compact, dwarf habit similar to 'Micro-Tom' in greenhouse experiments conducted in 1998 (Table 1). However, observations over several seasons indicate that 'Micro-Tina' plants are slightly larger than 'Micro-Tom' plants, but are much smaller than other dwarf cultivars, such as 'Red Robin' or 'Yellow Canary', when grown without root-zone restriction. However, when grown in small containers in 1998, the height or width of 'Micro-Tina' did not always differ statistically from that of 'Red Robin' or 'Yellow Canary' (Table 1).

1. This is document HS986, a publication of the Horticultural Sciences Department, Florida Cooperative Extension Service, IFAS, University of Florida. Publication date: June 2004. Please visit the EDIS Website at http://gcrec.ifas.ufl.edu.

2. J.W. Scott, professor, and B.K. Harbaugh, professor, Gulf Coast Research and Education Center, Bradenton, Florida Cooperative Extension Service, IFAS, University of Florida, Gainesville, FL 32611; E.A. Baldwin, research leader, USDA/ARS, Citrus and Subtropical Products Laboratory, Winter Haven, FL 33880 .

The Institute of Food and Agricultural Sciences (IFAS) is an Equal Opportunity Institution authorized to provide research, educational information and other services only to individuals and institutions that function with non-discrimination with respect to race, creed, color, religion, age, disability, sex, sexual orientation, marital status, national origin, political opinions or affiliations. U.S. Department of Agriculture, Cooperative Extension Service, University of Florida, IFAS, Florida A. \& M. University Cooperative Extension Program, and Boards of County Commissioners Cooperating. Larry Arrington, Dean 
As with the previously released miniature dwarf cultivars, all plant parts are genetically reduced, allowing for well-porportioned growth in small containers. Nonminiature dwarf cultivars are larger and plant size is restricted by constriction of the root zone in the small containers.

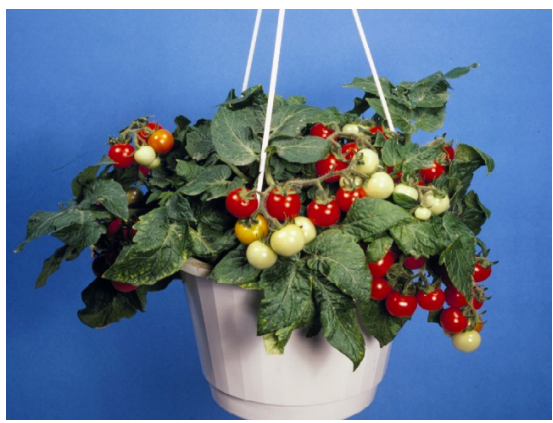

Figure 1. 'Micro-Tina'.

Pedicels are jointed and the fruit have uniform green ( $u$ gene) shoulders. They ripen to an attractive red color with a glossy exterior. Fruit are trilocular, resembling a miniature large fruit, as oppsed to a cherry tomato fruit whch is bilocular and has a larger locule : pericarp ratio. 'Micro-Tina' has fruit comparable in size to those of 'Micro-Tom' and smaller than those of 'Red-Robin' and 'Yellow Canary'. Fruit ripen earlier than for 'Micro-Tom' and the other cultivars tested (Table 1).

Fruit of 'Micro-Tina' are less acid and sweeter than those of 'Micro-Tom', according to an experienced tast panel (33 people) and objective measurements of acid and sugars (Table 2). Overall flavor did not differ statistically from that of 'Micro-Tom', but was better than that of 'Red Robin'. The taste panel rated 'Red Robin' as less aicd, a feature supported by the measurement of citric acid. Our objective was to develop a miniature, red-fruited, dwarf tomato with a sweeter flavor than 'Micro-Tom', and the data in Table 2 indicate that this objective was achieved.

'Micro-Tina' is resistant to fusarium wilt race 1 [Fusariumoxysporum Schlechtend.f.sp. lycopersic (Sacc.) Snyder and Hansen] (I) and gray leafspot (Stempyllium solani Weber) (Sm). Fruit are highly tolerant to major fruit disorders such as blossom end rot, cracking, and graywall.

\section{'Micro-Gemma'}

Plant habit of 'Micro-Gemma' was similar to 'Micro-Tina' in Spring and Fall 1998 (Table 1). It tended to be smaller than 'Micro-Gold', espcially in the Fall experiment (Table 1).

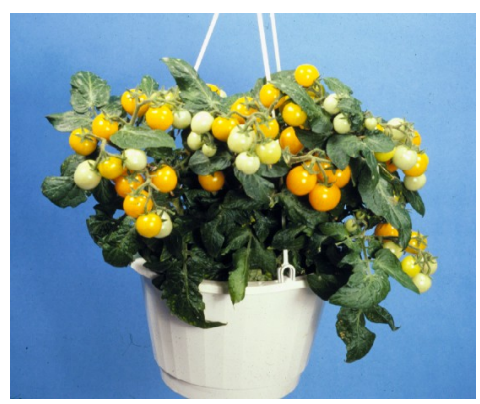

Figure 2. 'Micro-Gemma'.

'Micro-Gemma' has jointed pedicel and fruit have uniform green $(u)$ shoulders. Fruit ripen to a gold color because of the yellow flesh allele $(r)$ and the yellow epidermis color $(Y)$. Internal fruit anatomy is similar to that of 'Micro-Tina'. Fruit size is similar to that of other dwarf cultivars and smaller than that of 'Red Robin' and 'Yellow Canary' (Table 1). It is not as early as 'Micro-Tina', but is similar in maturity to 'Micro-Tom' and 'Micro-Gold'.

The experienced taste panel did not detect significant differences in sweetness or overall flavor among the three yellow-fruited cultivars tested (Table 2). However, chemical measurements indicated that 'Micro-Gemma' was higher in soluble solids and sucrose equivalents than 'Micro-Gold' and 'Yellow Canary'. In numerous field and greenhouse comparisons, the authors rated the flavor of 'Micro-Gemma' as better than that of 'Micro-Gold'. It has the same disease resistance as 'Micro-Tina'.

\section{Seed Availability}

'Micro-Tina' and 'Micro-Gemma' are open-pollinated (pure line) releases. Distribution for commerical seed production purposes is handled through the Florida Foundation Seed Producers, P.O. Box 309, Greenwood, FL 32443. Small samples for research purposes are available from the senior author. 


\section{Literature Cited}

Koehler, P.E. and S.J. Kays. 1991. Sweet potato

flavor; Quantitative and qualitative assessment of

optimum sweetness. J. Food Qual. 14:241-249.

Scott, J.W. and B.K. Harbaugh. 1989.

Micro-Tom, a miniature dwarf tomato. Florida Agr.

Expt. Sta. Circ. S-370.

Scott, J.W. and B.K. Harbaugh. 1995.

Micro-Gold miniature dwarf tomato. HortScience

30:643-644. 
Table 1. Evaluations of plant and fruit characteristics of six tomato cultigens grown as single plants in pots $(13 \mathrm{~cm}$ in diameter, $1 \mathrm{~L})^{z}$ or three plants in hanging pots $(20 \mathrm{~cm} \text { in diamter, } 2.2 \mathrm{~L})^{\mathrm{y}}$ under greenhouse conditions in Spring and Fall $1998^{\mathrm{x}}$, Bradenton, FL.

\begin{tabular}{|c|c|c|c|c|c|c|}
\hline \multirow[b]{3}{*}{ Cultigen } & & & \multicolumn{4}{|c|}{ Fruit } \\
\hline & \multicolumn{2}{|c|}{ Plant } & \multirow[b]{2}{*}{$\begin{array}{l}\text { Diam } \\
(\mathrm{mm})^{\mathrm{w}}\end{array}$} & \multirow[b]{2}{*}{$\begin{array}{l}\text { Wt } \\
(g)^{w}\end{array}$} & \multirow[b]{2}{*}{$\begin{array}{c}\text { No. per } \\
\text { container }^{v}\end{array}$} & \multirow{2}{*}{$\begin{array}{l}\text { Time } \\
\text { to color } \\
\text { (d) }\end{array}$} \\
\hline & $\begin{array}{l}\mathrm{Ht} \\
(\mathrm{cm})\end{array}$ & $\begin{array}{l}\text { Width } \\
(\mathrm{cm})\end{array}$ & & & & \\
\hline \multicolumn{7}{|l|}{ Red-fruited } \\
\hline Micro-Tina & $11.2 b^{t}$ & \multicolumn{4}{|c|}{22.2 a Single ptabtoper 13-c16. Spring 42 a } & $91 \mathrm{c}$ \\
\hline Micro-Tom & $11.6 \mathrm{~b}$ & $20.0 \mathrm{ab}$ & $23.2 \mathrm{c}$ & $7.9 \mathrm{~b}$ & $39 a$ & $100 a b$ \\
\hline Red Robin & $20.0 \mathrm{a}$ & $17.4 \mathrm{bc}$ & $26.7 \mathrm{~b}$ & $14.5 \mathrm{a}$ & $29 \mathrm{bc}$ & $100 a b$ \\
\hline \multicolumn{7}{|l|}{ Yellow-fruited } \\
\hline Micro-Gemma & $12.0 \mathrm{~b}$ & $18.6 \mathrm{bc}$ & $22.2 \mathrm{c}$ & $6.2 \mathrm{~b}$ & $37 a b$ & $98 \mathrm{~b}$ \\
\hline Micro-Gold & $12.8 \mathrm{~b}$ & $22.0 \mathrm{a}$ & $21.1 d$ & $7.7 \mathrm{~b}$ & $36 a b c$ & $100 a b$ \\
\hline Yellow Canary & $19.6 \mathrm{a}$ & $16.0 \mathrm{c}$ & $29.3 \mathrm{a}$ & $14.7 \mathrm{a}$ & $28 \mathrm{c}$ & $103 \mathrm{a}$ \\
\hline Red-fruited & \multicolumn{6}{|c|}{ Single plant per $13-\mathrm{cm}$, Fall } \\
\hline Micro-Tina & $23.2 \mathrm{bc}$ & $23.2 \mathrm{bc}$ & $21.8 \mathrm{c}$ & $5.5 \mathrm{c}$ & $45 \mathrm{a}$ & $71 d$ \\
\hline Micro-Tom & $18.8 \mathrm{c}$ & $24.4 \mathrm{bc}$ & $20.2 \mathrm{c}$ & $4.5 \mathrm{c}$ & $48 \mathrm{a}$ & $78 \mathrm{bc}$ \\
\hline Red Robin & $25.0 b^{v}$ & $25.7 \mathrm{~b}$ & $27.7 \mathrm{a}$ & $9.2 \mathrm{~b}$ & $25 \mathrm{c}$ & $85 \mathrm{a}$ \\
\hline \multicolumn{7}{|l|}{ Yellow-fruited } \\
\hline Micro-Gemma & $19.2 \mathrm{c}$ & $22.4 \mathrm{bc}$ & $21.8 \mathrm{c}$ & $5.9 \mathrm{c}$ & $34 \mathrm{bc}$ & $75 c$ \\
\hline Micro-Gold & $25.2 \mathrm{~b}$ & $21.2 \mathrm{c}$ & $21.9 \mathrm{c}$ & $6.1 \mathrm{c}$ & $35 \mathrm{~b}$ & $81 \mathrm{~b}$ \\
\hline Yellow Canary & $31.4 \mathrm{a}$ & $28.9 \mathrm{a}$ & $24.1 \mathrm{~b}$ & $12.3 \mathrm{a}$ & $33 \mathrm{bc}$ & $88 \mathrm{a}$ \\
\hline & \multicolumn{6}{|c|}{ Three plants per 20-cm hanging pot, Spring } \\
\hline \multicolumn{7}{|l|}{ Red-fruited } \\
\hline Micro-Tina & $13.3 d$ & $35.0 \mathrm{a}$ & $24.9 \mathrm{bc}$ & $8.0 \mathrm{c}$ & $100 \mathrm{a}$ & $92 \mathrm{c}$ \\
\hline Micro-Tom & $15.7 \mathrm{~cd}$ & $30.8 \mathrm{ab}$ & $23.9 \mathrm{~cd}$ & $7.1 \mathrm{c}$ & $92 \mathrm{a}$ & $99 \mathrm{~b}$ \\
\hline Red Robin & $22.0 \mathrm{ab}$ & $29.3 b$ & $27.7 \mathrm{a}$ & $15.6 \mathrm{a}$ & $62 \mathrm{~b}$ & $102 a b$ \\
\hline \multicolumn{7}{|l|}{ Yellow-fruited } \\
\hline Micro-Gemma & $14.7 \mathrm{~cd}$ & $29.8 \mathrm{ab}$ & $22.4 \mathrm{de}$ & $6.8 \mathrm{c}$ & $95 \mathrm{a}$ & $97 \mathrm{bc}$ \\
\hline Micro-Gold & $19.0 \mathrm{bc}$ & $34.3 \mathrm{ab}$ & $21.4 \mathrm{e}$ & $8.3 \mathrm{c}$ & $64 \mathrm{~b}$ & $101 \mathrm{ab}$ \\
\hline \multirow[t]{2}{*}{ Yellow Canary } & $25.3 \mathrm{a}$ & $29.5 b$ & $27.0 \mathrm{ab}$ & $12.1 \mathrm{~b}$ & $59 \mathrm{~b}$ & $105 \mathrm{a}$ \\
\hline & \multicolumn{6}{|c|}{ Three plants per $20-\mathrm{cm}$ hanging pot, Fall } \\
\hline \multicolumn{7}{|l|}{ Red-fruited } \\
\hline Micro-Tina & $28.3 \mathrm{bc}$ & $42.1 \mathrm{ab}$ & $21.7 \mathrm{c}$ & $5.7 \mathrm{~cd}$ & $86 a$ & $70 \mathrm{c}$ \\
\hline Micro-Tom & $24.7 \mathrm{c}$ & $46.3 \mathrm{a}$ & $21.5 \mathrm{c}$ & $7.9 \mathrm{abc}$ & $92 \mathrm{a}$ & $79 \mathrm{~b}$ \\
\hline Red Robin & $32.7 \mathrm{~b}$ & $39.8 \mathrm{~b}$ & $26.2 \mathrm{a}$ & $10.0 \mathrm{a}$ & $37 c$ & $88 \mathrm{a}$ \\
\hline \multicolumn{7}{|l|}{ Yellow-fruited } \\
\hline Micro-Gemma & $27.3 \mathrm{bc}$ & $43.8 \mathrm{ab}$ & $21.2 \mathrm{c}$ & $6.8 \mathrm{bcd}$ & $65 \mathrm{~b}$ & $78 \mathrm{~b}$ \\
\hline Micro-Gold & $40.7 \mathrm{a}$ & $40.1 \mathrm{~b}$ & $23.9 \mathrm{~b}$ & $5.4 \mathrm{~d}$ & $63 \mathrm{~b}$ & $82 \mathrm{~b}$ \\
\hline Yellow Canary & $34.0 \mathrm{~b}$ & $43.7 \mathrm{ab}$ & $23.8 \mathrm{~b}$ & $8.1 \mathrm{ab}$ & $56 \mathrm{~b}$ & $87 \mathrm{a}$ \\
\hline
\end{tabular}


Table 1. Evaluations of plant and fruit characteristics of six tomato cultigens grown as single plants in pots (13 cm in diameter, $1 \mathrm{~L})^{\mathrm{z}}$ or three plants in hanging pots $(20 \mathrm{~cm} \text { in diamter, } 2.2 \mathrm{~L})^{\mathrm{y}}$ under greenhouse conditions in Spring and Fall $1998^{\mathrm{x}}$, Bradenton, FL.

\footnotetext{
${ }^{\mathrm{z}}$ The experimental design was a randomized complete block with five replications, and a single plant was the experimental unit.

${ }^{y}$ The experimental design was a randomized complete block with three replications, and the experimental unit consisted of three plants.

x Seeding dates 9 Jan. (Spring) and 19 Aug. (Fall).

w Average for the first five fruit to ripen per plant.

$\checkmark$ Number of green and ripen fruit $=2$ weeks after first fruit color.

$\mathrm{u}$ Days from seeding to first appearance of true fruit color.

t Mean separation within columns, containers, and season by Duncan's multiple range test; significant at $P \leq 0.05$.
}

Table 2. Experienced taste panel (33 people) evaluation of flavor components and chemical anaylsis of acids and sugars of dwarf tomato genotypes at Bradenton, FL in Spring 1998.

\begin{tabular}{|c|c|c|c|c|c|c|}
\hline \multirow[b]{2}{*}{ Genotype } & \multicolumn{3}{|c|}{ Taste panel } & \multicolumn{3}{|c|}{ Chemical analysis } \\
\hline & Acidity & Sweetness & $\begin{array}{l}\text { Overall } \\
\text { flavor }\end{array}$ & $\begin{array}{c}\text { Citric } \\
\text { acid (\%) }\end{array}$ & $\begin{array}{l}\text { Soluble } \\
\text { solids }\end{array}$ & $\begin{array}{c}\text { Sucrose } \\
\text { equalivants }\end{array}$ \\
\hline \multicolumn{7}{|l|}{ Red-fruited } \\
\hline Micro-Tina & $4.09 b^{y}$ & $5.69 a$ & $5.56 \mathrm{a}$ & 0.48 & 5.3 & 6.08 \\
\hline Micro-Tom & $4.97 \mathrm{a}$ & $4.31 \mathrm{~b}$ & $4.72 a b$ & 0.82 & 4.2 & 2.81 \\
\hline Red Robin & $2.97 \mathrm{C}$ & $5.19 a b$ & $4.16 b$ & 0.37 & 4.2 & 3.66 \\
\hline \multicolumn{7}{|l|}{ Yellow-fruited } \\
\hline Micro-Gemma & $4.55 \mathrm{a}$ & 5.24 & 5.36 & 0.38 & 5.7 & 5.00 \\
\hline Micro-Gold & $4.27 \mathrm{a}$ & 4.73 & 4.94 & 0.68 & 4.8 & 3.20 \\
\hline Yellow Canary & $3.15 b$ & $\begin{array}{c}4.73 \\
\text { NS }\end{array}$ & $\begin{array}{l}4.52 \\
\text { NS }\end{array}$ & 0.42 & 4.5 & 3.13 \\
\hline \multicolumn{7}{|c|}{$\begin{array}{l}\text { A measure of relative sweetness based on sucrose where percentages of glucose and fructose } \\
\text { were multipled by } 0.74 \text { and } 1.73 \text {, respectively (Koehler and Kays, 1991). } \\
\text { y Mean separation within columns and fruit colors by Duncan's multiple range test at } P<0.05 \text {. } \\
\text { NS Nonsignificant. }\end{array}$} \\
\hline
\end{tabular}

